\title{
Participatory management and organizational involvement of employees in Sub-Saharan Africa
}

\author{
Kutche Tamghe Chevalier de Dieu \\ School of Management, Panafrican Institute of Development, PO box 35527, Yaoundé-Cameroon \\ * E-mail of the corresponding author: Kutchevalier2002@yahoo.fr
}

\begin{abstract}
This article aims to analyze the effects of participatory management on the organizational involvement of employees in Halliburton, in a context marked by an increased search for performance and in an increasingly competitive environment. To achieve this, we conducted a quantitative survey of 451 employees of Halliburton and Perenco firms in Central and West Africa, in order to request their assessment of the level of implementation of participatory management in the company. as well as their organizational involvement. The descriptive analysis of the data shows that the participative management is strongly implanted in the firms and that the level of organizational involvement of employees is interesting. The inferential analysis through the simple linear regression indicates that there is a positive and significant influence of the participative management on the organizational implication of the employees of the firms. These results are discussed in the perspective of Stashevsky and Elizur, 2000; Charles-Pauvers and Schieb-Bienfait, 2012; Stervinou, 2014 and Mahieu, 2017, whose conclusions go in the same direction as ours and suggest that maintaining this style of management and extending it to all employees would contribute to improving their organizational involvement.
\end{abstract}

Keywords: Participatory Management, Participation, Organizational Involvement, Affective Involvement, Calculated Involvement, Normative Involvement

DOI: $10.7176 / \mathrm{EJBM} / 11-36-15$

Publication date: December $31^{\text {st }} 2019$

\section{Introduction}

The international economic environment is characterized by an economic crisis that impacts all businesses leading managers to the awareness of the need to make the most of the human resource. To this end, companies are constantly looking for the best way to encourage the organizational involvement of their employees, as it is recognized as an important lever for overall performance (Neveu and Thevenet, 2002). As Veniard (2011) points out, it is important to know how, in this new context characterized by instability, unpredictability and fear, to found a form of reciprocal loyalty in labor relations that could condition the involvement of employees. Offshoring, corporate closures, restructuring and profound changes, which can punctuate the life of some companies, lead the HRD to invent a new way of managing human resources that combine flexibility and efficiency in search of efficiency. This is truer for multinationals, especially those in the oil sector such as Halliburton and Perenco, whose permanent fluctuations in oil prices on the world market greatly impact their profitability.

To maintain a high level of HR competitiveness, companies consider employee participation as one of the most appropriate models. According to Mahieu (2017), Participatory Management is a process where subordinates share significant degree of decision-making power with their superiors. Then, it is a management system, designed to overcome conflicts of interest to encourage the identification and attachment of staff to the company and to obtain a broad consensus on priority objectives. For Stervinou (2014) and Davister (2006) the participative management style is an important catalyst for employee motivation and organizational involvement.

With the above developments, we want to know if participative management influences the organizational involvement of employees in multinationals in sub-Saharan Africa. For this, we formulate the following research hypothesis: Participatory management has an effect on the organizational involvement of employees in subSaharan Africa. To verify this presumption, we opted for a quantitative approach and regression analysis. Thus, at first, we will analyze the literature concerning the relation participative management and the organizational implication. We will then describe the methodology used for the empirical part of our study. Finally, we will 
present the results and the discussion in the light of previous studies.

\section{Review of the literature}

By choosing to examine the link between participative management and the organizational involvement of employees, this study aims to place the human resource at the center of the business project. The idea of reorganizing the work in the direction of a greater involvement of the worker emerges in the 19th century in the working class in reaction to the conditions caused by the industrial revolution and capitalism. Its advocates thus share the will to instill better working conditions, to provide better protection, to break the hierarchical model in place, to establish democratic rights within the company as well as to ensure the management of this one (Mahieu, 2017).

The pioneering work on participatory management is McGregor's $\mathrm{X}$ and $\mathrm{Y}$ two theories. It is based on the observation that there is no satisfactory theory of the management function because no one accounts for the potential of human resources in the company (McGregor, 1960). Its model is intended to influence the type of leadership to adopt depending on the group concerned. The $\mathrm{X}$ theory presents an authoritarian and centralized mode of management to answer the incapacity of the men to take responsibilities, to their natural dislike for their work, to their immaturity, to their need to be directed to advance. On the other hand, theory Y corresponds to a mode of participative management which is based essentially on the desire of the employees to be fulfilled and to exercise responsibilities. For him, men are all capable of creativity, work can be a source of satisfaction and human potential can be a source of satisfaction. Maslow (1970) later demonstrated the limits of the theory Y during his experimentation. Some people remain vulnerable to taking responsibility, which is why it proposes to develop this responsibility, but to adapt it according to each person's possibilities. Beyond this vision, participative management can answer our problem because, as McGregor (Op cit) indicates, people exercise selfdirection and self-control in the accomplishment of organizational objectives insofar as they are concerned. These objectives and managerial policies and practices materially affect their level of commitment.

For its part, Likert (1961) analyzed the various management systems in order to compare which ones best answered the problems of personnel management without resorting to the classical or technocratic approach. His main contribution is the fact that he highlighted the causal relationship that exists between, on the one hand, the nature of interactions between officials and subordinates and, on the other hand, management styles by explaining that the latter largely depend on the way in which the manager deals with his subordinates. Thus, he distinguishes four management styles: exploitative authoritarian management, paternalistic authoritarian management, advisory management and participative management. Through participatory management, Likert (1961) refers to the type of management that includes employees in the decision-making process, thereby creating their commitment to the company, which will reinforce their sense of innovation and improve their performance. According to Dewandre (2009), the involvement of workers in the management of the company is regularly highlighted in Western companies and seems, in general, to be considered as positive and bear a real interest for workers and for the company. According to Collard (2013), participation must be understood as a democratization of the management of the enterprise to involve the employee.

From the above, participative management seems to be a kind of "co-construction" and would rely on a certain involvement of employees and their regular participation in decision-making concerning the company or organization as Mahieu thinks (2017). This management is based on five main principles: the delegation of power, communication and mutual respect, the trust of management towards employees, the responsibility for organizational prosperity, and an active policy of staff development.

Conscious of all the benefits that this style of management can offer, the multinational firms Halliburton and Perenco have incorporated into their managerial practices the five fundamental principles aiming to promote the participation and organizational involvement of its employees enacted by Likert (1961). It involves the mobilization of staff, the application of an active policy of personal development, the delegation of power, the resolution of each problem at its level of occurrence, and the establishment of regulation. The implementation of these different principles should allow a better organizational involvement of the employees of the company.

The organizational implication that Meyer and Allen (1991) also call organizational commitment is a multidimensional concept that refers to an employee's commitment to his or her organization, and this 
psychological state has consequences for the decision to do so. stay a member for Mowday, Porter and Steers (1982), involvement is characterized by a strong belief in the goals and values of the organization, a willingness to make significant efforts to benefit the organization, and a strong desire to remain a member.

According to Neveu and Thevenett (2002), the organizational theories of the contract, and consequently of implication, are organized around two main poles namely: the transactional type contract (calculated mode of exchange), and that of relational type (communion mode, affective mode). He uses the term "commitment" to translate a positive attitude of the person into the organization and considers that the term "organizational commitment" translates a commitment and a positive attitude of the employee towards the organization. According to Meyer and Allen (1991), three dimensions of organizational involvement can be identified: emotional, calculated and normative involvement. Affective involvement refers to the emotional attachment, identification and involvement of the employee with respect to their organization (Müller and Djuatio, 2011). Employees with strong emotional involvement remain in the organization by desire. This dimension is considered to be the best predictor of work efficiency (Bentein, Foucher, Morin and Trottier, 2004). Normative involvement manifests itself in attitudes of loyalty and duty. It reflects a predisposition to act in the interests of the organization. The calculated implication or commitment of continuity, highlights the cost generated by the departure of the organization. Employees with a strong calculated involvement remain in the organization by need (Meyer and Allen 1991) and may eventually experience frustrations that could make their work unsuitable (Bentein, Foucher, Morin and Trottier, 2004).

The empirical literature has frequently negatively linked these three dimensions to turnover and the intention to leave (Meyer and Herscovitch, 2001). However, affective involvement is positively associated with better individual and collective performance, as well as a reduction in the number of delays and absenteeism (Meyer an Allen, 1991). Defining the organizational implication, Pozzo di Borgo (2012) notes that the employee who is involved is part of the company and that one feels at home an aspect of investment, commitment. Involvement is for him a moral contract, a risk taking appealing to courage. Then, there can be no implication without a real appropriation of the collective project communicated by the management team which is also called "the Meaning". To mobilize each employee, he must listen to it, ensure its autonomy, allow him to express what is "worth for him" while being part of the values of the company. According to him, human resources management and internal communication tools must measure employee involvement in order to make it a real lever for social performance. As for Roussel, Dalmas and Oubrayrie (2009), the involvement of employees is highly valued by contemporary organizations in that a simple compliance with formal requirements does not make it possible to survive in a very dynamic competitive context.

Ping Wang (2011) considers that involvement is like vigor, dedication and concentration at work. It seems linked to increased productivity and a lower turnover rate. Many of the concepts used in organizational behavior are related to involvement, including motivation, engagement, involvement, commitment to organization, initiative, and loyalty (Kutche, 2019).

Inspiring from Ping Wang (2011), an employee of Halliburton or Perenco will be said to be involved if he is dedicated and focused in his work and if his intention of departure in case of a better opportunity is not great. The employee involved is happy to be a member of the organization for which he or she works and he or she does everything in his power to stay with it (Meyer and Allen, 1991).

While employee involvement is now one of the major challenges for the performance of organizations, it must be underpinned by a quality relationship between employers and employees (Kutche, 2019). Indeed, several authors have been interested in the question of the link between participative management and organizational involvement. Thuderoz (1995) conducted a study of more than 400 employees of different companies. The results of this one reveal that they are more than $92 \%$ to judge that the participation allowed to share their expertise and their knowledge. Charles-Pauvers and Schieb-Bienfait (2012), for their part, conducted a qualitative study among the managers of a firm that opted for participative management. Following their interviews, they conclude that participation promotes organizational involvement and is a real competitive advantage for the company. In addition, Stashevsky and Elizur (2000) conducted surveys of a sample of 208 employees to measure the impact of participation in decision-making on productivity. Their results show that workers have increased their performance through their participation in decision-making. However, Mahieu (2017) believes that we need to consider the factors that make it possible to increase involvement in participatory 
management. For him, involving employees in decision-making stimulates their involvement and reduces absenteeism by an average of 51\%. Charles-Pauvers and Schieb-Bienfait (2012) as well as Stervinou (2014) note through their work that some employees are more involved and more easily carry out actions for the benefit of their companies because of the sharing of democratic values conveyed by the participation and because of positive interactions with colleagues. Dewandre (2009) indicates that it is about "management democracy" and "to involve the various stakeholders - and especially the workers - in decision-making contributes to the democratic ideal of the company". From the above, it appears that participative management seems to be seen as a source of employee value, motivation and organizational involvement.

\section{Methodology}

The data was collected from a random sample of 451 employees from multinational firms based in Central and West Africa, namely: Halliburton Cameroon $(\mathrm{N}=54)$, Perenco Cameroon $(\mathrm{N}=58)$, Halliburton Gabon $(\mathrm{N}=51)$, Halliburton Congo $(\mathrm{N}=50)$, Halliburton Mauritania $(\mathrm{N}=43)$, Halliburton Mali $(\mathrm{N}=36)$, Perenco Gabon $(\mathrm{N}=$ 56), Perenco DRC $(\mathrm{N}=55)$; Perenco Congo $(\mathrm{N}=48)$. The participants were contacted individually through internal networks. The disparity in the number of respondents is due to the size of the workforce, which differs according to the countries mentioned, as well as to the unavailability of certain employees to answer our questionnaire. The study was presented to them as academic research aimed at improving the understanding of the effect of management style on their organizational involvement. To guarantee confidentiality, the questionnaire was sent by email to each employee. The average age of respondents is 38 , while $41 \%$ of respondents are female. In terms of work experience, more than $60 \%$ of the respondents have at least five years of experience in each of the firms. Also, the vast majority of respondents are senior technicians and engineers (283). 72, are executives and 96 are employed in the administration.

To test our assumptions, we must first ensure the quality and reliability of our measuring instruments. Frequency analysis will allow us to assess the level of relevance or implementation of participative management in these companies as well as the level of organizational involvement of employees. Since our valid sample is 451 employees, we consider the items whose increasing cumulative percentage of opinions to be on modality 3 representing the neutral or indecisive opinion on the Likert scale (1961) as irrelevant and not well implemented. Only the opinions representing modalities 4 and 5 on the scale will correspond to the relevant participatory management practices that are well established. The same procedure will be applied for organizational involvement. It will follow a test of reliability or internal consistency through the analysis of the Apha Cronbach $(\alpha)$ which determines to a large extent the analysis of dimensionality. This will be done through the method of factorial analysis of multiple correspondences, since our study variables mobilized are essentially qualitative. The Cronbach Alpha coefficient was 0.6 for the exploratory study and 0.8 for the confirmatory study. For the analysis of the quality we selected the axes whose average variance presented is greater than $50 \%$. The test of our hypotheses will be done through simple linear regression. It will seek and establish the type of relationship between participatory management and organizational involvement from a linear equation.

The measure of the level of organizational involvement was done using the Meyer and Allen (1991) scale. The measuring instrument consists of 18 items, ie 6 for each dimension of organizational involvement. The response modalities are inspired by Likert (1961) in five points, from strongly disagree (1) to strongly agree (5). To avoid the effect of Halo and contamination items of the three components of involvement (emotional, normative and calculated) were mixed. To measure the level of integration of participative management in firms, we took the scale of Beddache and Azzoug (2018) and adapted it to our context. This scale has 6 items. In general, the scales showed satisfactory psychometric qualities:

Regarding the organizational implication, the AFCM allowed us after purification to retain 6 items including two (2) for each dimension of the variable. These items are: The company has a lot of personal meaning for me; I feel a strong sense of belonging to this company; I would feel guilt if I left the company; I do not leave the company for the moment because I feel a sense of obligation towards the people who are part of it; if I had not given so much to myself, I could have considered working elsewhere; far too many things would be disturbed in my life if I decided to leave the company now. 
Table 1: Test of Reliability and Quality of Scale of Organizational Involvement Models Summary

\begin{tabular}{|c|c|c|c|c|}
\hline \multirow{2}{*}{ Dimension } & Alpha of Cronbach & \multicolumn{3}{|c|}{ Variance represented } \\
\cline { 2 - 5 } &, 948 & 4,766 &, 794 & Total (Eigenvalue) \\
\hline 1 &, 674 & 2,280 &, 380 & 79,434 \\
\hline 2 & & 7,046 & 1,174 & 37,995 \\
\hline Total &, $859^{\mathrm{a}}$ & 3,523 &, 587 & 58,714 \\
\hline Average & & & \\
\hline
\end{tabular}

a. The average of Alpha of Cronbach is based on the avreage eigienvalue.

The reliability and quality test of this scale indicates a satisfying Alpha of Cronbach $\alpha=0.85$ and an interesting average of the variance presented $\mathrm{Vp}=58.71 \%$ (Table 1 ).

With regard to participatory management, the AFCM allowed us to select five (05) items representing the entire scale of the variable. It's about : you participate with your managers in making decisions and setting goals ; your managers value your creativity and suggestions; you trust your managers and maintain good relations with them; you place a high value on teamwork; you feel fully associated with the management of the company and your opinion matters.

Table 2: Test of reliability and quality of the participatory management scale Models Summary

\begin{tabular}{|c|c|c|c|c|}
\hline \multirow[b]{2}{*}{ Dimension } & \multirow[b]{2}{*}{ Alpha of Cronbach } & \multicolumn{3}{|c|}{ Variance represented } \\
\hline & & Total (Eigenvalue) & Inertia & $\%$ of variance \\
\hline 1 & ,935 & 3,971 & ,794 & 79,415 \\
\hline 2 &, 575 & 1,852 & ,370 & 37,039 \\
\hline Total & & 5,823 & 1,165 & \\
\hline Average &, $821^{\mathrm{a}}$ & 2,911 &, 582 & 58,227 \\
\hline
\end{tabular}

a. The average of Alpha of Cronbach is based on the avreage eigienvalue.

The reliability and quality test of this scale indicates a satisfying Alpha of Cronbach $\alpha=0.82$ and an interesting average variance presented $\mathrm{Vp}=58.22 \%$ (Table 2 ).

\section{Results of the study}

Table 3 shows that organizational involvement in companies is satisfactory (mean $=3.99)$. The percentage of employees who seem very involved in the company is $53.44 \%$. On the other hand $46,56 \%$ are undecided, which seems to indicate that they do not feel very attached to the company. 
Table 3: Appreciation of organizational implication

\begin{tabular}{|c|c|c|c|c|c|}
\hline \multicolumn{2}{|c|}{ Modality } & Frequency & Percentage & $\begin{array}{c}\text { Cumulative } \\
\text { percentage }\end{array}$ & Average \\
\hline \multirow{3}{*}{ Valid } & 3 & 210 & 46,56 & 46,56 & \\
\cline { 2 - 5 } & 4 & 198 & 43,90 & 90,46 & \multirow{2}{*}{3,99} \\
\cline { 2 - 5 } & 5 & 43 & 9,54 & 100,0 & \\
\cline { 2 - 5 } & Total & 451 & 100,0 & & \\
\hline
\end{tabular}

Table 4 indicates that the participative management style is very well established in firms $($ mean $=4.08)$. The percentage of employees who consider themselves sufficiently associated with the management of the company is $64.97 \%$. On the other hand, $35,03 \%$ feel that they are not sufficiently involved by their managers in decisionmaking and their implementation.

Table 4: Appreciation of the level of integration of participative management

\begin{tabular}{|l|c|c|c|c|c|}
\hline \multicolumn{2}{|c|}{ Modality } & Frequency & Percentage & $\begin{array}{c}\text { Cumulative } \\
\text { percentage }\end{array}$ & \multirow{2}{*}{ Average } \\
\hline Valid & 3 & 158 & 35,03 & 35,03 & \multirow{2}{*}{4,08} \\
\cline { 2 - 5 } & 4 & 233 & 51,66 & 86,69 & \\
\cline { 2 - 5 } & 5 & 60 & 13,31 & 100,0 & \\
\cline { 2 - 5 } & Total & 451 & 100,0 & & \\
\hline
\end{tabular}

The results of the regression analyzes are shown in Table 5 below. As expected, the analysis of the coefficients of determination reveals a score which makes it possible to affirm that the participative management is positively and significantly related to the organizational implication of the employees $\left(R^{2}=0.61\right.$, variation of $F$ significant with $\mathrm{p} \leq 0.01)$. Residue analysis through the Durbin-Watson test $(1.76)$ shows that these are correctly distributed and follow a regression line.

Table 5: Model Summary of the participatory management regression on teachers organizational commitment

Model Summary

\begin{tabular}{|c|c|c|c|c|c|c|c|c|c|c|}
\hline \multirow[b]{2}{*}{ Model } & \multirow[b]{2}{*}{$\mathrm{R}$} & \multirow[b]{2}{*}{$\begin{array}{c}\mathrm{R} \\
\text { Square }\end{array}$} & \multirow[b]{2}{*}{$\begin{array}{l}\text { Adjusted } \\
\text { R square }\end{array}$} & \multirow[b]{2}{*}{$\begin{array}{l}\text { Std Error of the } \\
\text { Estimate }\end{array}$} & \multicolumn{5}{|c|}{ Change Statistiques } & \multirow[b]{2}{*}{$\begin{array}{l}\text { Durbin- } \\
\text { Watson }\end{array}$} \\
\hline & & & & & $\begin{array}{c}\text { R Square } \\
\text { Change }\end{array}$ & F Change & $\mathrm{d} 11$ & $\mathrm{~d} 12$ & $\begin{array}{c}\text { Sig. F } \\
\text { Change }\end{array}$ & \\
\hline 1 &, $785^{a}$ & ,616 & ,615 & ,30051 & ,616 & 718,993 & 1 & 449 & ,000 & 1,762 \\
\hline
\end{tabular}

a. Predictors : (Constante), Participatory Management

b. Dependant Variable : Organizational Involvement 
The analysis of the regression coefficients (Table 6) reveals a standardized beta very satisfactory for the model $(\beta=0.78)$, a Student's $T$ positive and very significant with $\mathrm{P}<0.01$. These results suggest that participatory management has a positive and very significant influence on the organizational involvement of employees.

Table 6 : Parameters of the regression model

Coefficients $^{a}$

\begin{tabular}{|l|r|r|r|r|r|r|r|}
\hline \multirow{2}{*}{ Model } & \multicolumn{2}{|c|}{$\begin{array}{c}\text { Unstandardized } \\
\text { Coefficients }\end{array}$} & $\begin{array}{c}\text { standardized } \\
\text { Coefficients }\end{array}$ & $\mathrm{t}$ & Sig. & \multicolumn{2}{c|}{$\begin{array}{c}\text { Collinearity } \\
\text { statistics }\end{array}$} \\
\cline { 2 - 9 } & \multicolumn{1}{c|}{ B } & $\begin{array}{c}\text { Std } \\
\text { Error }\end{array}$ & Bêta & & & Tolerance & VIF \\
\hline 1 (Constant) &, 734 &, 122 & & 6,002 &, 000 & & \\
$\quad$ Participatory Management &, 799 &, 030 &, 785 & 26,814 &, 000 & 1,000 & 1,000 \\
\hline
\end{tabular}

a. Dependant Variable : Organizational Involvement

\section{Discussion}

Our study aimed to verify the influence of participative management on the organizational involvement of employees in firms Halliburton and Perenco. Descriptive analyzes have shown that participative management is strongly implanted in firms $(64.97 \%$ of employees consider themselves sufficiently associated with the management of the company). Moreover, they seem quite involved in their work (53.44\%). The results of the regression analysis show that participatory management has a very positive and significant effect on the organizational involvement of employees $\left(R^{2}=0.61, \beta=0.78\right.$, positive Student $T$ and very significant with $P<0$, $01)$.

Based on these results, our research hypothesis that participatory management has an effect on the organizational involvement of employees in multinational firms in sub-Saharan Africa is validated. This suggests that the organizational involvement of the employees of each of these firms will be all the greater, if its management style is participatory and extended to all employees, since some $(46.56 \%)$ remained undecided and seem not to be sufficiently involved in running the business.

In general, our results, corroborating those of most of the authors quoted in the literature, militate in favor of the improvement of the organizational implication through a better association of the employees with the management of the company. Charles-Pauvers and Schieb-Bienfait, 2012), for example, have shown that allowing employees the opportunity to become involved in decision-making increases the commitment of employees. Stashevsky and Elizur (2000) and Mahieu (2017) also established after their studies that participation in decision-making has a positive impact on worker attendance and motivation. Finally, Stervinou (2014) showed that participatory management increases the motivation of employees because of the addition of meaning to their work and the feeling of gratitude towards their expertise and their places within the organization.

Nevertheless, as indicated by Mahieu (2017), it is worth asking whether the will to participate is shared by all employees. According to him, some employees, ensure that not to participate does not represent suffering and that weighing in decisions is not a priority for them. In addition, some employees are not convinced that participation is a form of justice at work and therefore considers it more of a constraint than a benefit (Berthet et al., 2012). Therefore, without taking anything away from the importance of participatory management, it seems complicated to consider participatory management as a motivational factor for all employees when a part of them do not want it or even reject it.

\section{Conclusion}

The objective of this research was to analyze the influence of participative management on the organizational involvement of employees in multinational firms in Sub-Saharan Africa. Quantitative analysis revealed that participative management is strongly implanted in the company and that the general level of organizational involvement seems satisfactory. Indeed, the majority of employees believe that they are regularly involved in decision-making and implementation. They are regularly consulted by managers who take their opinions into consideration. However, it is important to take into account the share of employees who feel that they are not 
sufficiently involved in decision-making, as this feeling may be a factor of demotivation. Most of them are executing agents, technicians whose activities are closely controlled by the managers. In addition, the results show that the level of organizational involvement is satisfactory, since all three dimensions of organizational involvement (calculated, emotional and normative) are taken into account in the analysis. The simple linear regression allowed us to highlight a strong positive and significant influence of the participative management on the organizational commitment of the employees. Thus, the more employees of Perenco and Halliburton will be involved in decision-making and implementation, the more important their organizational involvement will be.

Our research enriches current knowledge on theories of mobilizing practices in management sciences and particularly on the determining factors of organizational involvement. By our results, the managers of the various firms as well as those of the companies of the oil sector in general have any interest to worry about the perception of the level of association of their employees with the management of the company, if they wish to maintain and significantly improve their organizational involvement and hence overall performance. It would be particularly useful to further develop group dynamics at all levels, to involve employees of all categories in decision making, while preserving the specificities of each of these categories in terms of the flow of information.

Despite the contributions of this study, it has a certain number of limits that deserve to be noted: we did not take into consideration the contingency factors such as the socio-demographic criteria of the employees which can be moderating factors in the relation between management style and organizational involvement. These limits open avenues of research for future studies that could incorporate moderator or mediator variables. One could also use the structural equation method that would cross the independent variable and several dependent variables at the same time by specifically distinguishing the effect of participatory management on each of the forms of organizational implication (affective, normative and calculated).

\section{References}

Baddache, D., \& Azzoug S. (2018). Management participatif et Leadership. Cas pratique: Spa Tchin Lait Bejaia. Mémoire de Master en Sciences de gestion, Université de Bejaia, 122 p.

Bentein, K., Foucher, R., Morin, L., \& Trottier, M. (2004). Mesurer l'implication : l'intérêt de combiner les indices d'engagement affectif et normatif. XVème Congrès AGRH, Montréal, pp. 1-4.

Berthet, G., Bosschaert, B., \& Marechal, P. (2012). Les travailleurs participent-ils à la gestion des entreprises. Lille, Les cahiers de l'observatoire transfrontalier de l'ESS, 4, 20 p.

Blondiaux, L. (2008). Le nouvel esprit de la démocratie : Actualité de la démocratie participative. Paris, Seuil, $112 \mathrm{p}$.

Charles-Pauvers, B., \& Schieb-Bienfait N. (2012). Manager des collectifs, levier de la compétence organisationnelle? Étude de cas dans une société coopérative et participative. Travail et emploi, 130, 57-75.

Collard, M.-C. (2013). Démocratisons l'économie! Pratiques et utopies. Monceau-sur-Sambre: SAW-B, Les dossiers de l'économie sociale, $156 \mathrm{p}$.

Dewandre, A. (2009). La participation des travailleurs à la gestion. Prolonger la réflexion. Monceau-SurSambre : SAW-B, Analyse, 9 p.

Kutche, T.C.D. (2019). Pratiques de GRH et performance sociale dans les établissements du secondaire public au cameroun. Thèse de doctorat en GRH, IPD-AC, $324 \mathrm{p}$.

Likert, R. (1961). New Patterns of Management Hardcover. US, McGraw-Hill Inc, 279 p.

Mahieu G. (2017). Les effets du management participatif sur la productivité du travailleur et l'efficacité économique de l'entreprise. Mémoire de Master, Université de Louvain, 87 p.

Maslow, A. (1954). Motivation and personality. New York, Harper and Row, 399 p.

McGregor, D. (2008). The human side of enterprise. McGraw-Hill Education, 480 p.

Meyer, J. P., \& Allen, J. N. (1991). Three component conceptualization of organizational commitment. Human Resource Management Review, 1(1), 61-89.

Meyer, J.P. et Herscovitch, L. (2001). Commitment in the workplace Toward a general model. Human Resource Management Review, 11, 299-326.

Mowday, R., Steers R., \& Porter L. (1979). The measurement of organizational commitment. Journal of Vocational Behavior, 14, 224-227. 
Müller, J. et Djuatio, E. (2011). Les relations entre la justice organisationnelle, l'employabilité, la satisfaction et l'engagement organisationnel des salariés. Revue de gestion des ressources humaines, (82)4, 46-62. doi:10.3917/grhu.082.0046.

Neveu, J. P., \& Thevenet, M. (2002). L'implication au travail. Paris, Vuibert, 230 p.

Ping Wang (2011). La motivation: une source efficace pour améliorer la performance des membres d'équipes de projet. Mémoire de Maitrise en gestion des projets, Université du Québec.

Roussel, P., Dalmas, M. et Oubrayrie-Roussel, N. (2009). Les modèles intégrateurs de la motivation au travail. In Rojot, J., Roussel, P. et Vandenberghe, C. Comportement Organisationnel, 3(6), 235-249.

Stashevsky, S., \& Elizur, D. (2000). The effect of quality management and participation in decision-making on individual performance. Journal of quality management, 5, 53-65.

Stervinou, S. (2014). Les Scop: des entreprises au management participatif?. Ergologia, Société internationale d'ergologie, 95-130.

Thuderoz, C. (1995). Du lien social dans l'entreprise. Travail et individualisme coopératif. Revue française de sociologie, 36(2), 325-354.

Véniard, A. (2011). Implication et employabilité : un engagement réciproque entre salarié et employeur à construire. Management et Avenir, 49(9), 84-101. 